\title{
Sepsis in Canadian children: a national analysis using administrative data
}

This article was published in the following Dove Press journal:

Clinical Epidemiology

5 December 2014

Number of times this article has been viewed

\author{
Graham C Thompson' \\ Niranjan Kissoon ${ }^{2}$ \\ 'Alberta Children's Hospital, \\ University of Calgary, Calgary, AB, \\ Canada; ${ }^{2}$ British Columbia Children's \\ Hospital, University of British \\ Columbia, Vancouver, BC, Canada
}

Correspondence: Graham C Thompson Alberta Children's Hospital, University of Calgary, 2888 Shaganappi Trail NW, Calgary, T3B 6A8 AB, Canada Tel +l 4039557295

Fax + I 4039557552

Email graham.thompson@

albertahealthservices.ca
Background: Severe infection resulting in sepsis is recognized as a leading cause of morbidity and mortality worldwide. The purpose of this study is to use longitudinal, population-based data to report national-level hospital metrics, providing a current assessment of the status of sepsis hospitalizations in Canadian children.

Methods: We performed an analysis of previously abstracted data from the Canadian Institute for Health Information (CIHI) Discharge Abstract Database (DAD). Children aged 0-17 years at the time of hospital admission were identified from a cohort of patients with sepsis or severe sepsis using the International Classification of Diseases and Related Health Problems, 10th Revision (ICD-10-CA) and the Canadian Classification of Health Interventions (CCI). Descriptive population-based statistics are reported.

Results: Hospitalization data for 20,130 children admitted over 5 years were reviewed. The majority of children were young, with neonates (56.3\%) and infants under 2 months $(18.8 \%)$ representing the majority of cases. A decline in age-adjusted hospitalization rates was demonstrated in both overall and non-severe sepsis across the study period; however, no change was demonstrated for severe sepsis. While overall in-hospital crude mortality rates did not change significantly across the study period (range 5.1\%-5.4\%), a significant decrease was found in children aged 3-23 months and adolescents. Multi-organ failure was reported in more than onequarter of children with severe sepsis. Odds of mortality increased significantly with number of organs failed.

Conclusion: Sepsis remains an important cause of morbidity and mortality in Canadian children, posing a significant burden on health care resources. Age continues to be associated with the incidence and severity of illness. Overall hospitalization rates have declined over time, as has mortality in severe sepsis. This report provides baseline metrics for future outcome-based research in Canada targeting prevention strategies and early diagnosis, as well as therapies preventing and managing organ failure.

Keywords: septic shock, child, hospitalization, mortality, epidemiology

\section{Introduction}

Severe infection resulting in sepsis is recognized as a leading cause of morbidity and mortality worldwide. ${ }^{1-3}$ The incidence of sepsis in developed nations has been increasing while overall mortality is decreasing, but still remains high. ${ }^{3,4} \mathrm{~A}$ recent populationbased review of the status of sepsis hospitalization in the general population (all ages) across Canada determined a crude mortality rate of 30.5\% in 2008-2009. ${ }^{5}$ Moreover, morbidity in survivors is often functionally devastating, and may include neurological impairment, chronic organ dysfunction, increased days admitted to hospital, and high 
rates of mortality postdischarge.$^{6-9}$ Emotional, social, and financial costs to individuals and health care systems are immense. ${ }^{10-12}$

Recent administrative database analyses indicate that hospitalization rates for severe sepsis have significantly increased amongst adults in the US, while overall mortality rates have decreased. ${ }^{13}$ However, a dramatic difference in terms of incidence and mortality related to sepsis has been shown in the pediatric population when compared to adults. Previous studies from developed nations have shown a decrease in pediatric mortality related to sepsis to $<10 \%$ in the early 2000s. ${ }^{3}$ Advancements in preventative care, including population-wide immunization practices and routine postnatal care guidelines, have likely made significant contributions to these noted improvements. Likewise, optimizing management in health care centers through liberal use of fluid resuscitation, early antibiotics, and intensive care management has improved patient outcomes. ${ }^{14-18}$

Despite the successes of these primary care initiatives, children in developed and developing countries alike continue to suffer from the consequences of sepsis. ${ }^{7}$ As such, there has been renewed interest in resuscitation efforts and advanced management strategies in the care of the septic child. To optimize interventions and build capacity in any setting, an understanding of the current burden and disease trends is vital. However, robust information to guide Canadian pediatric initiatives is currently lacking.

The purpose of this study is to use longitudinal, population-based data in order to report national-level hospital metrics, providing a current assessment of the status of sepsis hospitalizations in Canadian children. This data is intended to represent the current burden of sepsis in children in Canada and will be used as baseline data to which future outcome-based improvement interventions can be compared.

\section{Methods}

We performed a pediatric-specific analysis of previously abstracted data ${ }^{5}$ from the Canadian Institute for Health Information (CIHI) Discharge Abstract Database (DAD). $\mathrm{CIHI}$ is a national administrative data repository. All data provided to CIHI by Canadian hospitals is done on a voluntary basis. Data from the province of Quebec is not included in this analysis due to differences in data collection format and processes.

Details of the initial data abstraction have been previously described by Husak et al. ${ }^{5}$ A description of the methods specific to this secondary analysis is given below.

\section{Study setting}

Geographically, Canada is the world's second largest country comprised of ten provinces and three territories. The estimated population in Canada (in millions) during the years 2004-2008 were 31.941, 32.245, 32.576, 32.927, and 33.318, respectively (http://www5.statcan.gc.ca/cansim/). Health care in Canada is publicly funded and governed nationally by the Canada Health Act, while services are provided under the jurisdiction of the provincial or territorial governments.

\section{Study population}

Children aged 0-17 years at the time of hospital admission were identified from a cohort of patients with sepsis or severe sepsis (see definitions below). The initial cohort was determined using the International Classification of Diseases and Related Health Problems, 10th Revision (ICD-10-CA) and the Canadian Classification of Health Interventions (CCI) (Table S1). Children were classified into the following age groups based on age at time of hospital admission: neonates (newborns that had not been discharged from hospital), young infants (0-2 months), older infants (3-23 months), preschool (2-4 years), school-aged (5-12 years), and teen (13-17 years). Patients whose sex was not recorded as "male" or "female", who were not admitted to acute care hospitals, or were not Canadian residents were excluded. Those with missing or invalid health card numbers, date of birth, and admission or discharge dates (required to construct episodes of care) were also excluded.

\section{Time frame}

Data were abstracted and grouped according to fiscal year, defined as April 1-March 31. Hospitalizations meeting the identified criteria of sepsis/severe sepsis with an admission date during fiscal years 2004/2005-2008/2009 were included.

\section{Definitions}

Sepsis, severe sepsis, and organ dysfunction definitions remained consistent with those used in the original database by Husak et al. ${ }^{5}$ Sepsis was defined using ICD-10-CA codes (Table S1). Severe sepsis was defined as sepsis with organ dysfunction in at least one of six systems, a definition typically used to define severe sepsis in administrative databases. Organ dysfunction was defined using ICD-10-CA codes and CCI codes (Table S2). The analysis was performed using one episode of care (defined as all contiguous inpatient acute care hospitalizations) as the base unit. Transfers from one center to another were accounted for by merging data; a transfer was assumed if admission to an acute care institution occurred on the same day or prior to discharge from the preceding acute 
Table I Characteristics of pediatric patients hospitalized with sepsis in Canada between 2004 and 2009

\begin{tabular}{|c|c|c|c|c|}
\hline & \multicolumn{3}{|c|}{ Sepsis - all comers } & \multirow{2}{*}{$\begin{array}{l}\text { Severe sepsis } \mathrm{n}(\% \text { severe } \\
\text { sepsis, \% all sepsis by age) }\end{array}$} \\
\hline & Male, n (\%) & Female, n (\%) & Total, n (\%) & \\
\hline Neonates & $6,312(55.7)$ & $5,013(44.3)$ & II,325 (56.3) & $2,605(58.7,23.0)$ \\
\hline $0-2$ months & $2,193(57.9)$ & $1,594(42.1)$ & 3,787 (18.8) & $648(14.6,17.1)$ \\
\hline $3-23$ months & 931 (54.3) & 782 (45.7) & I,7।3 (8.5) & $335(7.6,19.6)$ \\
\hline $2-4$ years & $537(54.2)$ & $453(45.8)$ & $990(4.9)$ & $202(4.6,20.4)$ \\
\hline $5-12$ years & 704 (54.8) & $580(45.2)$ & I,284 (6.4) & $303(6.8,23.6)$ \\
\hline $13-17$ years & $536(52.0)$ & $495(48.0)$ & I,03I (5.I) & $347(7.8,33.7)$ \\
\hline Total & $1|, 2| 3$ & 8,917 & $20,130(100)$ & $4,440(100,22.1)$ \\
\hline
\end{tabular}

care institution. For episodes with transfers between facilities, transactions were linked regardless of the most responsible diagnosis following the index admission. Length of stay (LOS) was calculated for episodes of care (from the time of the first admission till the last discharge time).

\section{Statistical analysis}

Descriptive population-based statistics are reported including proportions, means, and medians as appropriate. Odds ratios with $95 \%$ confidence intervals are reported where applicable. Rates of hospitalization are reported per 100,000 children. Linear regression was used to examine trends across the study period.

Crude mortality rates are reported by severity of disease, as well as by age group.

\section{Results}

Hospitalization data for 20,130 children aged 0-17 years with any diagnosis of sepsis during the 5-year study period were available for review. The majority of children were young, with neonates and infants under 2 months representing the majority of cases (56.3\% and $18.8 \%$, respectively). Males were more representative across all age groups. After the newborn period, severe sepsis demonstrated an increasing percentage of overall sepsis rates (Table 1 and Figure 1).

A decline in age-adjusted hospitalization rates was demonstrated in both overall and non-severe sepsis across the study period; however, no change was demonstrated for severe sepsis (Figure 2).

\section{Organ failure}

Table 2 reports the occurrence and mortality rates corresponding to the reported failure of individual organ systems. Multi-organ failure was reported in more than one-quarter of children with severe sepsis. Odds of mortality increased with number of organs failed (Table 3 ).

\section{Mortality}

While overall in-hospital crude mortality rates did not change significantly across the study period (range 5.1\%-5.4\%),

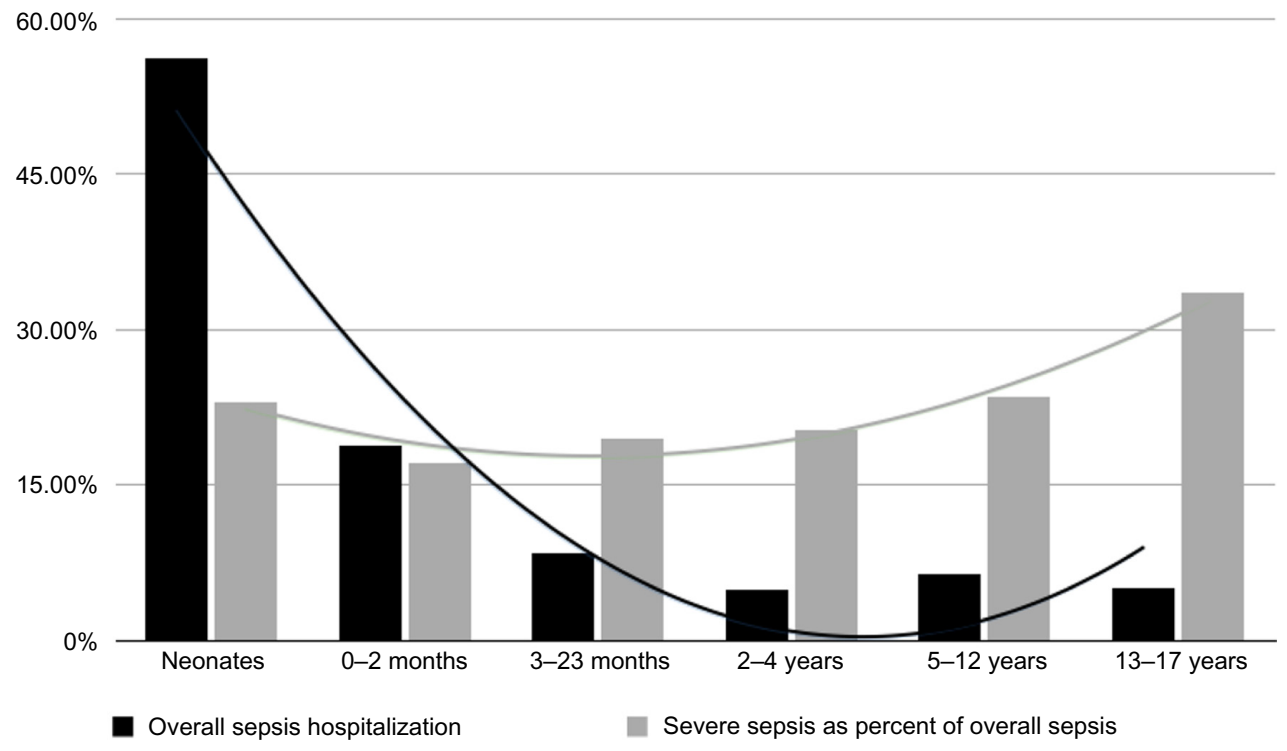

Figure I Comparison of percent of sepsis hospitalizations by severity and age. 


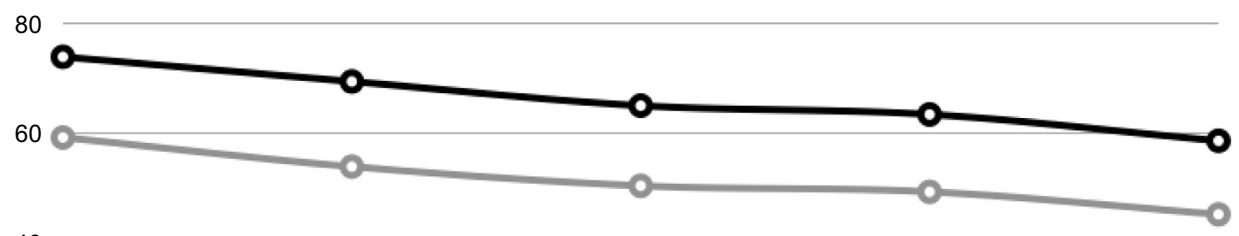

40

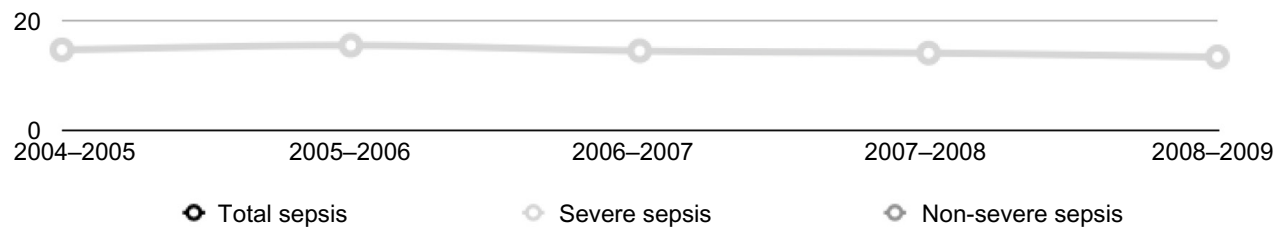

Figure 2 Age-adjusted hospitalization rates per 100,000 Canadian children.

a significant decrease in those with severe sepsis occurred (Figure 3). This reduction in mortality is attributed to declining mortality in two specific age groups; older infants (3-23 months) and adolescents (13-17 years; Figure 4).

\section{Hospital length of stay}

Data reporting hospital LOS were available only for the fiscal year 2008-2009. Overall LOS and intensive care unit (ICU) LOS are shown in Table 4, along with the proportion of children admitted to the ICU.

\section{Discussion}

To our knowledge, this is the first nation-wide epidemiologic report of sepsis amongst Canadian children. Our data shows that sepsis continues to be a significant health concern, with approximately 4,000 admissions and 200 deaths per year. We have demonstrated a significant decline in age-adjusted hospitalization rates for all children with diagnostic codes for sepsis, while crude mortality rates in this population remained constant over the 5 -year reporting period. Conversely, the mortality rate for children diagnosed with severe sepsis declined despite constant age-adjusted hospitalization. This may be explained by increased awareness of sepsis, more aggressive early man-

Table 2 Organ failure in Canadian children hospitalized with severe sepsis between 2004 and 2009

\begin{tabular}{lll}
\hline Organ system & n (\%) & Mortality, \% \\
\hline Respiratory & $691(81.2)$ & 17.5 \\
Cardiovascular & $202(23.7)$ & 21.3 \\
Hematologic & $103(12.1)$ & 26.2 \\
Renal & $96(11.3)$ & 25.0 \\
Hepatic & $25(2.9)$ & 56.0 \\
Central nervous system & $18(2.1)$ & 50.0 \\
\hline
\end{tabular}

agement, or improved access to intensive care facilities. Children with sepsis-related hospitalizations were found to have prolonged hospital LOS, and those with multiple organ failure were much more likely to die during their hospital stay.

As per similar studies of pediatric sepsis in developed countries, ${ }^{19-21}$ age plays a role in the epidemiology of disease; the neonatal population is significantly overrepresented. More than half of Canadian children diagnosed with sepsis are newborns, and $75 \%$ are $<2$ months of age. Similarly, $40 \%$ of children with severe sepsis were under 2 months. Interestingly, for those children in our cohort who were discharged from hospital after birth, severity of illness was associated with older age.

While Watson and Carcillo reported an increased incidence of severe sepsis in infant boys compared to girls, ${ }^{22}$ we found that the sex difference spanned all age groups. Ghuman et al have also reported sex-related differences in children with sepsis, demonstrating an increase in mortality and initial severity of disease, although differences were based on pubertal status. ${ }^{23}$ To our knowledge, the exact mechanism of the sex differences is still to be determined, although a hormonal mechanism via androgen suppression has been postulated. ${ }^{24}$

Table 3 Occurrence and mortality associated with organ dysfunction in Canadian children hospitalized for severe sepsis between 2004 and 2009

\begin{tabular}{llll}
\hline $\begin{array}{l}\text { Number of } \\
\text { organs failed }\end{array}$ & $\mathbf{n}(\%)$ & Mortality, \% & $\begin{array}{l}\text { Odds ratio } \\
\mathbf{( 9 5 \% ~ C l s )}\end{array}$ \\
\hline I system & $623(73.2)$ & 12.5 & 1.0 \\
2 systems & $188(22.1)$ & 27.1 & $7.2(3.6-14.3)$ \\
3 systems & $40(4.7)$ & 42.5 & $52.9(29.3-95.4)$ \\
\hline
\end{tabular}

Note: $95 \% \mathrm{Cls:} \mathrm{upper} \mathrm{and} \mathrm{lower} \mathrm{limits} \mathrm{on} 95 \% \mathrm{Cl}$.

Abbreviation: $\mathrm{Cl}$, confidence interval. 


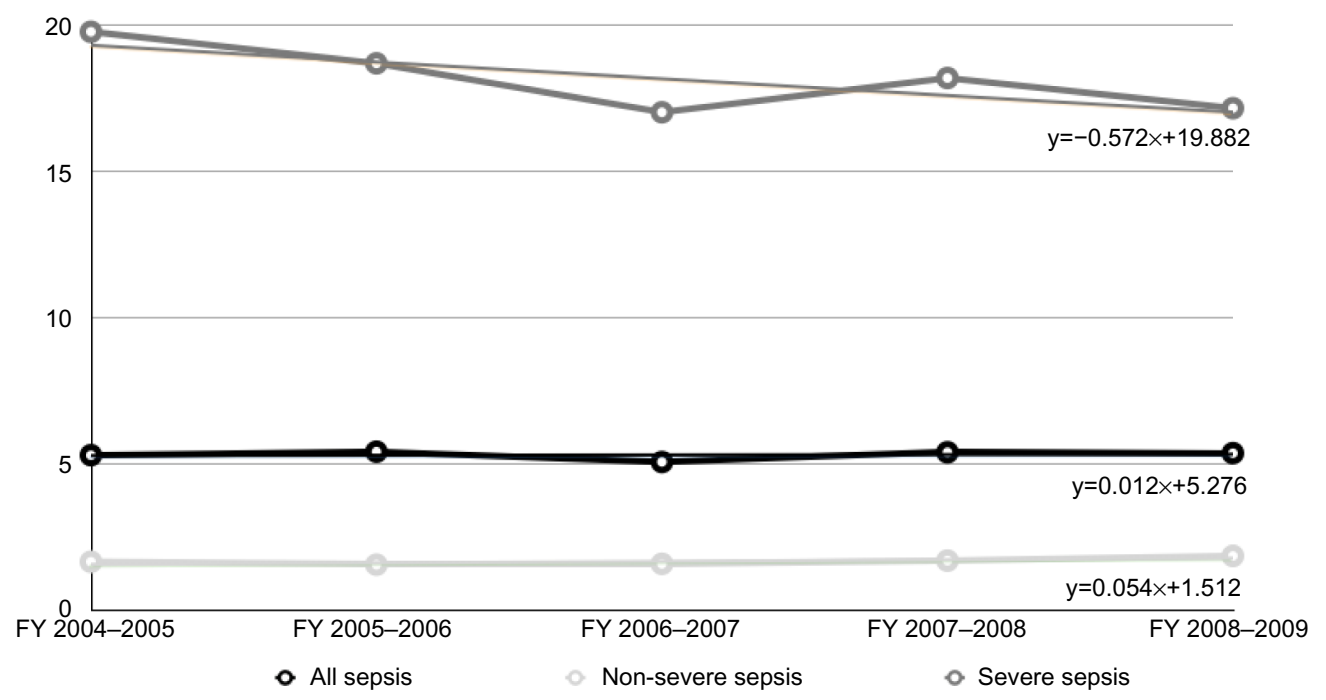

Figure 3 Crude sepsis mortality rates for hospitalized Canadian children by severity. Abbreviation: FY, fiscal year.

Organ failure commonly occurs in children with severe sepsis. In our cohort, respiratory failure occurred most frequently (81\%). Angus et $\mathrm{al}^{21}$ also demonstrated higher rates of mortality amongst adults with respiratory failure (46\%), although their numbers may be lower due to using a sample including all age spectrums. While very common in children with severe sepsis, the mortality rate in children with respiratory failure is fortunately less than $20 \%$. This is in comparison to children with hepatic or central nervous system failure, where mortality rates reach $50 \%$; this may be explained by a potential neuro-mediated suppression of killer cells residing in the liver, leading to increased susceptibility to overwhelm- ing disease leading to death. In addition, the number of organs failed was associated with odds of death.

During the study period, we found a significant decline in all-sepsis hospitalization rates over time. The introduction of pneumococcal and meningococcal vaccines into routine childhood immunization schedules has resulted in a significant decline in invasive disease attributed to these pathogens, which may be reflected in our reported rates of hospitalization. Across Canada, health care is governed by the Canada Health Act, though provincially administered; as a result, the timing of implementation of universal access to vaccines varies across the country. By 2006, conjugate

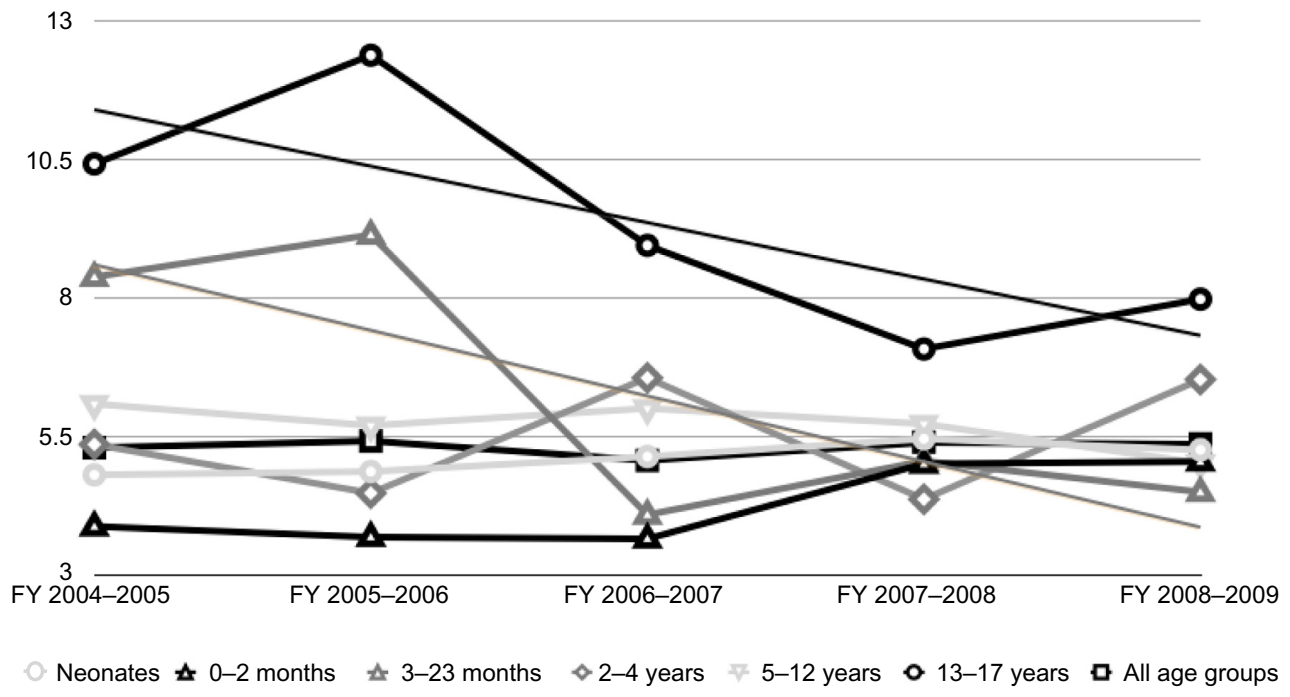

Figure 4 Crude sepsis mortality rates for hospitalized Canadian children by age. Abbreviation: FY, fiscal year. 
Table 4 LOS in Canadian children hospitalized for sepsis between 2004 and 2009

\begin{tabular}{lllll}
\hline & $\begin{array}{l}\text { Mean } \\
\text { LOS }\end{array}$ & $\begin{array}{l}\text { Median } \\
\text { LOS }\end{array}$ & $\begin{array}{l}\text { Mean } \\
\text { ICU LOS }\end{array}$ & $\begin{array}{l}\text { Median } \\
\text { ICU LOS }\end{array}$ \\
\hline All sepsis & 30.0 & 12.0 & 26.9 & 11.2 \\
Severe sepsis & 70.5 & 61.0 & 45.7 & 29.4 \\
Non-severe sepsis & 18.0 & 8.0 & 16.3 & 6.9 \\
\hline
\end{tabular}

Abbreviations: ICU, intensive care unit; LOS, length of stay.

pneumococcal vaccine was available across all Canadian jurisdictions, while meningococcal vaccine programs were instituted between 2002 and 2007. This may also explain the significant decline in mortality over the study period in children aged 2-4 years who, during the study, received pneumococcal and meningococcal vaccine. Similarly, mortality in teens (13-17 years of age) declined, which is potentially related to meningococcal vaccine strategies.

\section{Limitations}

The use of a national-level administrative database may impart selection and reporting bias to the integrity of the results. ICD-10-CA coding is the current standard across Canada, with rigorous data quality assessment through the CIHI. ${ }^{25-32}$ The additional factor of voluntary reporting to the CIHI database may increase this bias. Furthermore, given the exclusion of data from the province of Quebec due to reporting differences, selection bias may increase. However, this analysis (without Quebec) represented approximately $76.7 \%$ of the Canadian population in 2008 (http://www5.statcan.gc.ca/cansim/), and to our knowledge, there is no difference between those children included and those who were not included in the CIHI database. To our knowledge, this is the largest known Canadian database related to sepsis and provides an overall national picture of recent trends related to hospitalization due to sepsis in Canadian children. However, the data presented are likely an underestimation as they are based on the use of administrative definitions only, rather than including a clinical definition based on sepsis being "any severe infection associated with organ dysfunction". Additionally, sepsis episodes may be underreported having been coded using organ-specific infection instead of being classified as sepsis. Such limitations are inherent difficulties in determining the burden of sepsis globally. ${ }^{33-35}$ The definitions of sepsis, severe sepsis, and organ dysfunction based on the ICD-10-CA and CCI coding that were used in this study may not be consistent with those considered standard for pediatric sepsis in clinical studies. ${ }^{36}$ They are, however, consistent with previous studies regarding sepsis that rely on administrative data.
Similarly, coding systems at different hospitals may vary, and a standard method for documenting interventions and outcomes is required to ensure accurate and reproducible epidemiologic data. ${ }^{37}$ Given the nature of the secondary analysis of this study, the use of definitions from the original database reported by Husak et $\mathrm{al}^{5}$ was required.

Those children who presented to an emergency department (ED) with sepsis but died prior to hospital admission were not included in this analysis, as ED-specific data across the country were not available.

\section{Conclusion}

Sepsis remains an important cause of morbidity and mortality in Canadian children, posing a significant burden on health care resources. Age and sex continue to be associated with the incidence and severity of illness. Overall hospitalization rates have declined over time, as has mortality in severe sepsis. This report provides baseline metrics for future outcome-based research in Canada. Future research agendas may include targeting prevention strategies and early diagnosis as well as therapies preventing and managing organ failure.

\section{Acknowledgments}

The authors would like to express appreciation to Liudmila Husak and the analytic and administrative staff at the Canadian Institute for Health Information (CIHI) for their role in sharing and analyzing this dataset.

\section{Disclosure}

The authors report no conflicts of interest in this work.

\section{References}

1. Stehr SN, Reinhart K. Sepsis as a global health problem-why we need a global sepsis alliance. Shock. 2013;39 Suppl 1:3-4.

2. Schnitzler E, Iolster T. Burden of sepsis in children: perspectives from pediatric intensive care. Pediatr Crit Care Med. 2012;13(5):596-597.

3. Hartman ME, Linde-Zwirble WT, Angus DC, Watson RS. Trends in the epidemiology of pediatric severe sepsis*. Pediatr Crit Care Med. 2013;14(7):686-693.

4. Mayr FB, Yende S, Angus DC. Epidemiology of severe sepsis. Virulence. 2014;5(1):4-11.

5. Husak L, Marcuzzi A, Herring J, et al. National analysis of sepsis hospitalizations and factors contributing to sepsis in-hospital mortality in Canada. Healthc Q. 2010;13 Spec No:35-41.

6. Buysse CM, Raat H, Hazelzet JA, et al. Long-term health status in childhood survivors of meningococcal septic shock. Arch Pediatr Adolesc Med. 2008;162(11):1036-1041.

7. Farris RW, Weiss NS, Zimmerman JJ. Functional outcomes in pediatric severe sepsis: further analysis of the researching severe sepsis and organ dysfunction in children: a global perspective trial. Pediatr Crit Care Med. 2013;14(9):835-842.

8. Prescott HC, Langa KM, Liu V, Escobar GJ, Iwashyna TJ. Increased 1-year healthcare use in survivors of severe sepsis. Am J Respir Crit Care Med. 2014;190(1):62-69. 
9. Cuthbertson BH, Elders A, Hall S, et al. Mortality and quality of life in the five years after severe sepsis. Crit Care. 2013;17(2):R70.

10. Burchardi $\mathrm{H}$, Schneider H. Economic aspects of severe sepsis: a review of intensive care unit costs, cost of illness and cost effectiveness of therapy. Pharmacoeconomics. 2004;22(12):793-813.

11. Brun-Buisson C, Roudot-Thoraval F, Girou E, Grenier-Sennelier C, Durand-Zaleski I. The costs of septic syndromes in the intensive care unit and influence of hospital-acquired sepsis. Intensive Care Med. 2003;29(9):1464-1471.

12. Wright C, Wordsworth R, Glennie L. Counting the cost of meningococcal disease: scenarios of severe meningitis and septicemia. Paediatr Drugs. 2013;15(1):49-58.

13. Lagu T, Rothberg MB, Shieh MS, Pekow PS, Steingrub JS, Lindenauer PK. Hospitalizations, costs, and outcomes of severe sepsis in the United States 2003 to 2007. Crit Care Med. 2012;40(3):754-761.

14. Paul R, Neuman MI, Monuteaux MC, Melendez E. Adherence to PALS Sepsis Guidelines and Hospital Length of Stay. Pediatrics. 2012;130(2):e273-e280

15. Han YY, Carcillo JA, Dragotta MA, et al. Early reversal of pediatricneonatal septic shock by community physicians is associated with improved outcome. Pediatrics. 2003;112(4):793-799.

16. de Oliveira CF. Early goal-directed therapy in treatment of pediatric septic shock. Shock. 2010;34 Suppl 1:44-47.

17. Carcillo JA, Davis AL, Zaritsky A. Role of early fluid resuscitation in pediatric septic shock. JAMA. 1991;266(9):1242-1245.

18. Dellinger RP, Levy MM, Rhodes A, et al; Surviving Sepsis Campaign Guidelines Committee including the Pediatric Subgroup. Surviving sepsis campaign: international guidelines for management of severe sepsis and septic shock: 2012. Crit Care Med. 2013;41(2):580-637.

19. Singhal S, Allen MW, McAnnally JR, Smith KS, Donnelly JP, Wang HE. National estimates of emergency department visits for pediatric severe sepsis in the United States. PeerJ. 2013;1:e79.

20. Wang HE, Shapiro NI, Angus DC, Yealy DM. National estimates of severe sepsis in United States emergency departments. Crit Care Med. 2007;35(8):1928-1936.

21. Angus D, Linde-Zwirble W, Lidicker J, Clermont G, Carcillo J, Pinsky MR. Epidemiology of severe sepsis in the United States: analysis of incidence, outcome, and associated costs of care. Crit care. 2001;29(7):1303-1310.

22. Watson RS, Carcillo JA. Scope and epidemiology of pediatric sepsis. Pediatr Crit Care Med. 2005;6(Suppl 3):S3-S5.

23. Ghuman AK, Newth CJ, Khemani RG. Impact of gender on sepsis mortality and severity of illness for prepubertal and postpubertal children. J Pediatr. 2013;163(3):835-840. e1

24. Angele M, Pratschke S, Hubbard WJ, Chaudry IH. Gender differences in sepsis: cardiovascular and immunological aspects. Virulence. 2013; 5(1):12-19.

25. Canadian Institute for Health Information. Earning Trust: Key Findings and Proposed Action Plan from the Data Quality Strategies Study. Ottawa, ON: Canadian Institute for Health Information; 2003. Available at: http://www.cihi.ca/CIHI-ext-portal/pdf/internet/DAD_EARNING_ TRUST_2003_EN. Accessed September 4, 2014.
26. Canadian Institute for Health Information. Earning Trust-3 Years Later Ottawa, ON: Canadian Institute for Health Information; 2006. Available at: http://www.cihi.ca/CIHI-ext-portal/pdf/internet/EARNING_TRUST_ YEARS_LATER_EN. Accessed September 4, 2014.

27. Canadian Institute for Health Information [webpage on the Internet]. Data and Standards. Canadian Institute for Health Information. Available at: http://www.cihi.ca/CIHI-ext-portal/internet/EN/ Theme/standards+and+data+submission/cihi010687. Accessed September 4, 2014.

28. Canadian Institute for Health Information. CIHI Data Quality Study of the 2008-2009: Discharge Abstract Database. Ottawa, ON: Canadian Institute for Health Information; 2010. Available at: https://secure. cihi.ca/free_products/DAD_0809_Reabstraction_Study_Report_final_ EN.pdf. Accessed September 4, 2014.

29. Canadian Institute for Health Information. Data Quality of the Discharge Abstract Database Following the First-Year Implementation of ICD-10-CA/CCI - Final Report. Ottawa, ON: Canadian Institute for Health Information; 2004. Available at: https:// secure.cihi.ca/free_products/DAD_DQ_ICD10Report_e.pdf. Accessed September 4, 2014.

30. Canadian Institute for Health Information. Canadian Coding Standards for ICD-10-CA and CCI for 2008. Ottawa, ON: Canadian Institute for Health Information; 2007. Available at: https://secure.cihi.ca/ free_products/canadian_coding_standards_2008_e.pdf. Accessed September 4, 2014.

31. Walker RL, Hennessy DA, Johansen H, Sambell C, Lix L, Quan H. Implementation of ICD-10 in Canada: how has it impacted coded hospital discharge data? BMC Health Serv Res. 2012;12:149.

32. De Coster C, Li B, Quan H. Comparison and validity of procedures coded with ICD-9-CM and ICD-10-CA/CCI. Med Care. 2008;46(6): 627-634.

33. Wilhelms SB, Huss FR, Granath G, Sjöberg F. Assessment of incidence of severe sepsis in Sweden using different ways of abstracting International Classification of Diseases codes: difficulties with methods and interpretation of results. Crit Care Med. 2010;38(6):1442-1449.

34. Whittaker SA, Mikkelsen ME, Gaieski DF, Koshy S, Kean C, Fuchs BD. Severe sepsis cohorts derived from claims-based strategies appear to be biased toward a more severely ill patient population. Crit Care Med. 2013;41(4):945-953.

35. Weiss SL, Parker B, Bullock ME, et al. Defining pediatric sepsis by different criteria: discrepancies in populations and implications for clinical practice. Pediatr Crit Care Med. 2012;13(4):e219-e226.

36. Goldstein B, Giroir B, Randolph A; International Consensus Conference on Pediatric Sepsis. International pediatric sepsis consensus conference: definitions for sepsis and organ dysfunction in pediatrics. Pediatr Crit care. $2005 ; 6(1): 2-8$

37. Gaieski DF, Edwards JM, Kallan MJ, Carr BG. Benchmarking the incidence and mortality of severe sepsis in the United States. Crit Care Med. 2013;41(5):1167-1174. 


\section{Supplementary materials}

Table SI Sepsis occurrence by diagnosis, ICD-I0-CA codes

\begin{tabular}{|c|c|c|c|c|c|c|c|c|c|c|}
\hline \multirow[t]{2}{*}{ Diagnosis } & \multicolumn{2}{|c|}{ FY 2004-2005 } & \multicolumn{2}{|c|}{ FY 2005-2006 } & \multicolumn{2}{|c|}{ FY 2006-2007 } & \multicolumn{2}{|c|}{ FY 2007-2008 } & \multicolumn{2}{|c|}{ FY 2008-2009 } \\
\hline & $\begin{array}{l}\text { Number } \\
\text { of cases }\end{array}$ & $\%$ & $\begin{array}{l}\text { Number } \\
\text { of cases }\end{array}$ & $\%$ & $\begin{array}{l}\text { Number } \\
\text { of cases }\end{array}$ & $\%$ & $\begin{array}{l}\text { Number } \\
\text { of cases }\end{array}$ & $\%$ & $\begin{array}{l}\text { Number } \\
\text { of cases }\end{array}$ & $\%$ \\
\hline $\begin{array}{l}\text { Bacterial sepsis of newborn } \\
\text { unspec (P369) }\end{array}$ & I,7I4 & 37.24 & $\mathrm{I}, 48 \mathrm{I}$ & 33.9 & 1,525 & 36.38 & $\mathrm{I}, 458$ & 34.91 & $|, 23|$ & 31.53 \\
\hline Septicemia unspec (A4I9) & 688 & 14.95 & 599 & $|3.7|$ & 580 & 13.84 & 566 & 13.55 & 541 & 13.86 \\
\hline $\begin{array}{l}\text { Newborn sepsis due } \\
\text { to oth/unspec staph (P363) }\end{array}$ & 430 & 9.34 & 426 & 9.75 & 369 & 8.8 & 374 & 8.95 & 383 & 9.81 \\
\hline $\begin{array}{l}\text { Other bacterial sepsis } \\
\text { of newborn (P368) }\end{array}$ & 171 & 3.72 & 152 & 3.48 & 195 & 4.65 & 219 & 5.24 & 243 & 6.22 \\
\hline Neonatal candidiasis (P375) & 198 & 4.3 & 170 & 3.89 & 192 & 4.58 & 159 & 3.81 & 177 & 4.53 \\
\hline $\begin{array}{l}\text { Septicemia due to Escherichia } \\
\text { coli (A4I50) }\end{array}$ & 112 & 2.43 & 123 & 2.82 & 112 & 2.67 & 121 & 2.9 & 132 & 3.38 \\
\hline $\begin{array}{l}\text { Sepsis of newborn due } \\
\text { to Escherichia coli (P364) }\end{array}$ & 104 & 2.26 & 95 & 2.17 & 96 & 2.29 & 112 & 2.68 & 123 & 3.15 \\
\hline $\begin{array}{l}\text { Newborn sepsis due } \\
\text { to Streptococcus group B (P360) }\end{array}$ & 162 & 3.52 & 150 & 3.43 & 118 & 2.81 & 122 & 2.92 & 106 & 2.72 \\
\hline $\begin{array}{l}\text { Septicemia due to other } \\
\text { spec Staphylococcus (A4II) }\end{array}$ & 176 & 3.82 & 233 & 5.33 & 189 & 4.51 & 145 & 3.47 & 102 & 2.61 \\
\hline $\begin{array}{l}\text { Septicemia due to Streptococcus } \\
\text { pneumoniae (A403) }\end{array}$ & 122 & 2.65 & 99 & 2.27 & 91 & 2.17 & 101 & 2.42 & 98 & 2.51 \\
\hline Other spec septicemia (A4|88) & 89 & 1.93 & 91 & 2.08 & 77 & 1.84 & 90 & 2.15 & 84 & 2.15 \\
\hline $\begin{array}{l}\text { Septicemia due to } \\
\text { Staphylococcus aureus (A4I0) }\end{array}$ & 103 & 2.24 & 118 & 2.7 & 96 & 2.29 & 132 & 3.16 & 83 & 2.13 \\
\hline $\begin{array}{l}\text { Septicemia due to other } \\
\text { Gram-negative organisms (A4I5 }\end{array}$ & 45 & 0.98 & 55 & 1.26 & 41 & 0.98 & 72 & 1.72 & 77 & 1.97 \\
\hline $\begin{array}{l}\text { Other streptococcal } \\
\text { septicemia (A408) }\end{array}$ & 50 & 1.09 & 64 & 1.46 & 54 & 1.29 & 62 & 1.48 & 75 & 1.92 \\
\hline $\begin{array}{l}\text { Newborn sepsis due } \\
\text { to Staphylococcus aureus (P362) }\end{array}$ & 60 & 1.3 & 91 & 2.08 & 73 & 1.74 & 80 & 1.92 & 75 & 1.92 \\
\hline $\begin{array}{l}\text { Newborn sepsis oth/unspec } \\
\text { streptococci (P36I) }\end{array}$ & 70 & 1.52 & 55 & 1.26 & 69 & 1.65 & 75 & 1.8 & 69 & 1.77 \\
\hline $\begin{array}{l}\text { Septicemia due to Streptococcus } \\
\text { group A (A400) }\end{array}$ & 21 & 0.46 & 45 & 1.03 & 38 & 0.91 & 35 & 0.84 & 45 & 1.15 \\
\hline $\begin{array}{l}\text { Congenital herpes } \\
\text { viral infection (P352) }\end{array}$ & 22 & 0.48 & 23 & 0.53 & 26 & 0.62 & 23 & 0.55 & 38 & 0.97 \\
\hline $\begin{array}{l}\text { Septicemia due to } \\
\text { Pseudomonas (A4I5I) }\end{array}$ & 22 & 0.48 & 35 & 0.8 & 21 & 0.5 & 23 & 0.55 & 37 & 0.95 \\
\hline $\begin{array}{l}\text { Septicemia due to } \\
\text { Enterococcus (A4180) }\end{array}$ & 42 & 0.91 & 52 & 1.19 & 47 & 1.12 & 42 & 1.01 & 32 & 0.82 \\
\hline Candidal septicemia (B377) & 43 & 0.93 & 49 & 1.12 & 29 & 0.69 & 23 & 0.55 & 26 & 0.67 \\
\hline $\begin{array}{l}\text { Septicemia due to Streptococcus } \\
\text { group B (A40I) }\end{array}$ & 32 & 0.7 & 29 & 0.66 & 31 & 0.74 & 30 & 0.72 & 23 & 0.59 \\
\hline Total & 4,476 & 97.25 & 4,235 & 96.92 & 4,069 & 97.07 & 4,064 & 97.3 & 3,800 & 97.33 \\
\hline
\end{tabular}

Note: Those diagnoses with $<20$ hospitalization episodes are not included.

Abbreviations: FY, fiscal year; ICD-I0-CA, International Classification of Diseases and Related Health Problems, I0th Revision; oth, other; spec, specified; unspec, unspecified. 
Table S2 ICD-I0-CA and CCl coding for organ dysfunction

\begin{tabular}{|c|c|c|}
\hline System & ICD-IO-CA codes & CCl codes \\
\hline \multirow[t]{2}{*}{ Respiratory } & J96.0, J96.9, J80, R09.2 & I.GZ.3I.CA-ND, I.GZ.3I.CR-ND, I.GZ.3।. \\
\hline & & GP-ND with extent attribute = "EX" \\
\hline Cardiovascular & R57, 195.I, 195.8, 195.9 & \\
\hline Renal & NI7 & \\
\hline Hepatic & K72.0, K72.9, K76.3 & \\
\hline Neurologic & F05.0, F05.9, G93.I, G93.4, G93.80 & \\
\hline Hematologic & D69.5, D69.6, D65 & \\
\hline
\end{tabular}

Abbreviations: CCI, Canadian Classification of Health Interventions; ICD-I0-CA, International Classification of Diseases and Related Health Problems, I0th Revision.

\section{Publish your work in this journal}

Clinical Epidemiology is an international, peer-reviewed, open access, online journal focusing on disease and drug epidemiology, identification of risk factors and screening procedures to develop optimal preventative initiatives and programs. Specific topics include: diagnosis, prognosis, treatment, screening, prevention, risk factor modification,

Submit your manuscript here: http://www.dovepress.com/clinical-epidemiology-journal
Dovepress

systematic reviews, risk \& safety of medical interventions, epidemiology \& biostatistical methods, and evaluation of guidelines, translational medicine, health policies \& economic evaluations. The manuscript management system is completely online and includes a very quick and fair peer-review system, which is all easy to use. 